\title{
Candidate Teachers' Views on Implementation and Adoption of Democracy: Istanbul University Sample
}

\author{
Hüseyin Serin \\ Correspondence: Hüseyin Serin Faculty of Education, İstanbulUniversity, İstanbul, Turkey.
}

Received: December 22, 2016

Accepted: January 31, 2017

Online Published: March 10, 2017

doi:10.11114/jets.v5i4.2092

URL: http://dx.doi.org/10.11114/jets.v5i4.2092

\begin{abstract}
The aim of this study is to determinethe candidate teachers' views, who have pedagogical proficiency atHasan Ali Yucel education faculty, on implementation of organizational democracy according to gender and education variable. 370 of the candidate teachers who have graduate degree and continue undergraduate study atístanbul University voluntarily participated in the study. Şeker's (2010) scale named as " Adoption and Implementation of Organizational Democracy in Primary Schools according to Supervisors' and Teachers' Perceptions" was adapted and applied to candidate teachers. The five likert scale includes three dimensions; Participation in the Decision, Subsidiarity and Decentralization. EFA, CFA and $t$ tests were conducted on the data collected fromthe study. According to the findings ofthe study, it has been understood that there are no differences among candidate teachers' views on the implementation of organizational democracy scale, but there are meaningful differences among their views according to their educational level.
\end{abstract}

Keywords: organizational democracy, participation in the decision, subsidiarity, decentralization

\section{Introduction}

While democracy notion dates back toold Greek, organizational democracy notion also has started to be used in late years. And besides, especially workers emphasize the need of organizational democracy.

Democracy notion etymologically derives from the compound of "demo" and "kratos". First notion means "people" and the second one means "power". Therefore, "demoskratos" namely democracy, means "power of people" or "sovereignty of people". When you look it up inthe Turkish Language Association dictionary, it is understood that it comes from French and it is definedas a regime basing on popular sovereignty (TDK Turkish Dictionary 2017).

Jean Jacques Rousseau describes democracy notion, which means 'self-management of people", as '"Real democracy is a mission" from a different pointof view.

When preparing a learning environment for students to find a democracy which is close to the ideal, the importance of emphasizing of taking into consideration three basic principles like freedom, justice and equivalence comes on the scen Deweye (Aktan, 1999). When it was first used, democracy notion meant people or people representatives' having power. In the early periods when democracy notion was used, nothing was pointed out about the boundaries of power. Besides, with the proliferation of usage of democracy notion, some different values and principles such as direct democracy, representative democracy, participatory democracy, social democracy, liberal democracy etc. have been emphasized. It is also stated that there are notions like substantive rights, justice, equivalence, freedom, participation and preferencesamong some values and principles (Şişman, 2006). Required participation for democracy is only possible with educated individuals. Education is acknowledged as a pre-condition both to be a good citizen and to defend their rights (Karakütük, 2001). Democracy, apart from its being a regime, is primarily a way to live together and schools can be described as democratic organizations (Dewey, 2010).

Apart from democracy's being adopted and implemented as a regime, with its being used in the organizations, organizational democracy notion was propounded and started to be discussed. Organizational democracy notion is described diversely from one writer to another. The form of democracy lived at organization level is called as organizational democracy (Harrison \& Freeman, 2004). Organizational democracy is paving the way for expressing opinions freely, protecting personal rights, participating in the decision and multiple communications between the manager and people managed (Rizvi, 2005). Organizational democracy ensures organization members' participation at the phases of being organized and administration (Yazdan, 2009). It is also comprised of the phases; supervisors' sharing administrative power with inferiors, workers' participation in the decisions and granting workers authorization to complete their tasks effectively (Başaran, 1998a). 
Decision making which means to make a certain judgement by considering about a duty or an issue and choosing an option among many (Bursalığlu, 1991) is a process, which forms a community of works that results in a preference and, where there is a starting point and various tasks, activities and opinions follow one another. (Koçel, 2003).Participative decision making is a type of making decision where administrators give workers opportunity to participate in the decisions (Mulder \& Wilke, 1970). Literally, participative decision making is defined as a process where an administrator and a worker or a group of workers make a decision about an issue together (Vroom \& Yetton, 1973). Participative decision making is formed with an organization culture and organization culture strongly affects organizational behavior and performance. Organization culture organizes members' behaviors by means of social norms, shared values, shared mental models and social identities, and therefore results in organization members' getting togetheraround shared aims and behaving and thinking accordingly (Scholl 2003).

Organizational democracy is an understanding which allows the ones affected by organizational volition to participate in volition mentioned and taking decisions together. Organizational democracy is an approach that extends the mission of the corporation and propagates organization's social responsibility within the corporation. Organizational democracy adopts a compromising approach at using organizational volition (Sadykova \& Tutar, 2014).In order for compromising approach to occur, it is a necessity that employees need to participate in decision making. And, this reveals the existence of participative management in organizational democracy. Participative management is an essential of democratic management style. It stipulates that all individuals who are experts on the topic, responsible for implementing decisions and affected by the results of the decisions need to participate in decision (Kocabaş \& Gökbaş 2002).Employees who are motivated by participating in decisions adopt the organization and the sense of belonging increases according to Erdem (1996). An employee who thinks she/he contributed to decisions taken does not oppose the decisions but works more efficiently. Employees' motivation and job satisfaction increase with participation in decisions, the quality and quantity of work improveandabsenteeism and quitting job decrease. Participative decision making is a type of decision making in which administrators give their employees opportunity to involve in decisions (Mulder \& Wilke, 1970). Literally, participative decision making is defined as a decision making process in which an administrator and an employee or a group of employees make a decision about a subject together (Vroom \& Yetton, 1973).

It was understood that participative decision making both increased productivity and the quality of decisions made in field studies. While participative decision making creates a good organization atmosphere, it also consolidates the trust in the organization. Employees have the opportunity to learn how the decisions are made in the participative decision making. Participative decision making increases employees' moods andmotivation, job satisfaction and organizational loyalty. In addition, it improves sense of trust in organization and collaboration; participative decision making enables employees to understand organization's aims clearly. Participative decision making improves group identity, collaboration and coordination (Bakan\& Büyükbeşe, 2005).

Localization should also be attached importance where participating in the decision is succeeded. So, the other dominant component of the organizational democracy is localization; namely, it is the decentralization. Decentralization is the authorization of the autonomous corporations by centralized administrations (Ergün, 2006). Organizational democracy ensures freeing duties, making units autonomous and employees' participation in the administration (Başaran, 1998). In other words, centralized organization's not interfering local organizations is taken as the management of a local organization on local services by using its own resources and units (Atasayar, 2005).

Another element that is accepted as an essential for organizational democracy where organizations decentralized participate in decisions is subsidiarity. Organizational democracy's another dimension is subsidiarity which provides administrators with open and multiple communication channels to continuously get feedback from the ones managed (Stohl \& Cheney, 2001). It is needed to know what warrant means rather than assigning a warrant(subsidiarity) in organizational democracies.

Warrant is defined as the right of ordering and the power of ensuring obedience; a certain individual or a group's obeying certain orders, inferiors' willingly and unconditionally obeying the orders from superior (Dalton, 2004). The warrant is attached to a duty nottoa person. The warrant is assigned to competent authority, not to the person who occupies there (Can,1992). The warrant can be classified with regards to its features such as whether it is official or unofficial, whether it can be assigned or not, its resource (warrant that relies on law, warrant that relies on trust, warrant that relies on traditions); and also according to the personal characteristics of the person who assigns (relying on knowledge, attached to competent authority) and organization relations (Eren, 1993). While subsidiarity is defined as an organizational activity which is succeeded by the movement of warrants towards lower levels according to Özalp and other (1997), it is a superior's assigning some of his warrants to inferiors to use in the name of him according to Onaran (1974). According to Aşkun (1970), giving or transferring warrants from an administrator or an organizational unit to one another to accomplish some certain tasks is called as subsidiarity. If we are to make a common definition from all definitions, subsidiarity is superior's giving their authority to an inferior to exercise in the name of them. 
It is an obligation for the individuals who form an organization to live together in order to accomplish mutual goals. So, administration needs to prepare an ideal environment where individuals don't ignore each other. Therefore, democracy is a form of designing rather than a form of political organization. Democracy provides the right and opportunity to comment on any subject that affects individuals' lives (Delaunay, 2004). Democracy means a probability of taking responsibility for everyone. It is individuals' making conscious choices for the benefit of society. In parallel to this, school is a dominant element that has a responsibility in the process of democratic society's occurring. When we look at the mission of school in society, schools have to educate individuals for human rights and make them internalize democratic rules. On the other hand, school has to service as a lever to make democratic society occur. And this occurs with socialization. Socialization prepares environments for individuals to live together by stimulating justice, freedom and responsibility values in terms of common social rules. School forms micro society by increasing individuals' creativity with socialization. Even if to provide a negotiation on democracy idea in school seems relatively easy, the question 'how to build it' gains importance (Truchot,2004).

Most emphasized cognitive factor in organizational democracy is employees' perceptions of justice. Organizational justice is evaluated in terms of three aspects; distribution justice, procedure justice and interaction justice. When individuals perceive injustice, they have a tendency to decrease or hide their volunteering manners. In the event that an individual who perceives injustice doesn't thoroughly accomplish duties mentioned in formal job role, they know that they might be deprived of formal rewards (İşbaş1 2000).

Purpose of the study:The aim of this study is to indicate the candidate teachers' views, who have pedagogical proficiency atHasan Ali Yücel education faculty, on implementation of organizational democracy according to gender and education level.

\section{Methodology}

\subsection{Study Group}

This research is a descriptive study. The research has been conducted with participation of 436 teacher candidates who have pedagogical proficiency atİstanbul University Hasan Ali Yücel Education Faculty. 436 students who want to be teachers in fields of Turkish Language and Literature, Geography, Physical Education and Sports Sciences, Chemistry, Biology, Press and Accounting and want to have pedagogical proficiency voluntarily participated in this study in 2013-2014 fall semester. Data collected have thoroughly been handled and study has continued with a group of 370 people by excluding 76 scale forms that weren't filled in accord with data collection technique.

\subsection{Tools}

In this study, the validity and reliability studies of the Organizational Democracy scale with 36 items which Şeker (2010) used in his study entitled "The Level of Adoption and Implementation of Organizational Democracy in Elementary Schools according to Manager and Teacher Perceptions" were conducted. The three sub dimensions were determined as Subsidiarity, Participation in Decision, and Localization in accordance with the original of organizational democracy scale.

The organizational democracy scale that was used by Şeker (2010) was based on the voluntary participation of teacher candidates in the pedagogical formation training, which is the target group, and the views on applicability of organizational democracy. A total of 36 items including organizational democracy was used in the scale. A five-point Likert-type rating scale consisting of "never applicable, little applicable, moderately applicable, largely applicable and fully applicable " was used for the level of applicability of the participants' expressions. In the positive statements, the answers were scored from "never applicable" to "fully applicable "from "1" to "5". The appropriateness of the items in the Organizational Democracy scale has been examined by the expert who is familiar with the subject .The applications were applied personally by the researcher on the determined sample.

The structural validity of the OD scale was examined by using exploratory factor analysis (EFA) and confirmatory factor analysis (CFA). EFA focuses on producing a theoretical model related to feature measured, a small number of conceptually meaningful new variables, finding factors from the relationship among variables. On the other hand, the CFA is used in the analysis of accordance of data with measurement model which is empirically explored or basedon the opinion of experts on the base of theory (Büyüköztürk, 2002; Tabachncik \& Fidell, 2001).

\subsection{Factor Pattern of Organizational Democracy Scale}

In this study, exploratory factor analysis (EFA) was conducted on the data applied to the group of 436 students. Mahallanobis distance ( $\mathrm{p}=0.05$, sd: 36$)$ and $\mathrm{z}(-3,3)$ values related to total pointswere taken into consideration and the study was continued with the group of 370 students by keeping 76 data out of study. It is a necessity that KMO value is to be over 0.70 and Barlett test is to be meaningful in order for the data to be suitable for factor analysis (Büyüköztürk, 2013).Because Kaiser-Meyer-Olkin value related to OD scale is 0.863 and value of Bartlett's Test of Sphericity is under 
0.05 , it has been proved that it is compatible with factor analysis. It can be stated that OD scale is reliable. Pattern with three factors that weren't compatible with model has not been detected in the process without rotation conducted on 370 individuals in EFA after excluding items overlapped. When the same procedure was performed with rotation, it did not accord with model again. Because of these reasons, confirmatory factor analysis (CFA) was decided to conduct.

Confirmatory factor analysis (CFA) that can be shown as a proof of validity of a pattern measured was configured with three factor model; subsidiarity, participation in the decision and localization and it was analyzed in LISREL 8.7 package program. In measuring model, factor score related to indicator was equalized to $(\lambda) 1.00$ (MD1, MD20, MDd29) to represent each factor. In OD scale with 36 items, items' factor score came out to be over 0.30 and RMSEA, GFI and AGFI values were shown in table 1.

When Goodness of Fit Index (GFI) $\geq 0.90$, Comparative Fit Index (CFI) $\geq 0.90$ and Root Mean Square Error of Approximation (RMSEA) $\leq 0.06$ conditions are taken into consideration, the fact that measuring model is compatible with CFA at a reasonable level can be accepted (Brown, 2006;Hu \& Bentler, 1999). Also, that the value ( $\chi^{2} /$ sd value) that is obtained by dividing chi-square $\left(\chi^{2}\right)$ value by degrees of freedom is two and below shows that accordance is good (Şimşek, 2007).

Table 1. Some Values after Confirmative Factor Analysis

\begin{tabular}{|c|c|c|c|c|}
\hline Values & $\chi^{2} / s d$ & RMSEA & GFI & CFI \\
\hline 36 Items & 1,85 & 0,048 & 0,92 & 0,97 \\
\hline
\end{tabular}

The fact that $\chi^{2} / \mathrm{sd}$ value is $1,85<2$, GFI value is $0.92>0.90$, CFI value is $0,97>0.90$ and RMSEA value is 0,48 $<0.60$ in 36 items form of scale after CFA shown in table 1 shows that model data accordance is acceptable. Also, path diagram has been shown in figure 1. CFA results show that OD scale has a pattern with three dimensions.

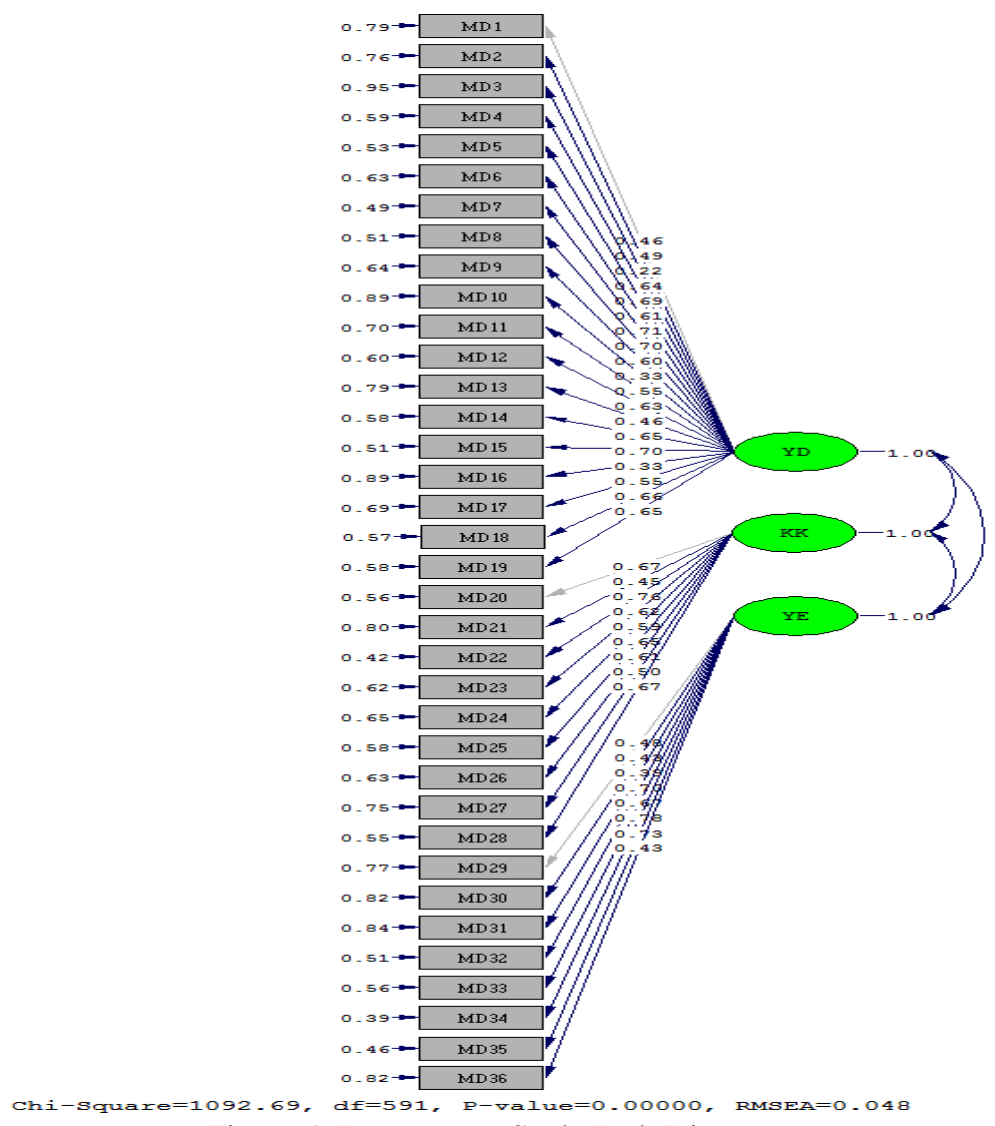

Figure 1. Democracy Scale Path Diagram

\section{Reliability}

Correlation values between items have been found below 0.80 and it was understood that there was no multiple connection problem. Also, Cronbach $\alpha$ coefficient seen as an important evidence of scale reliability has been found 0.857. Cronbach $\alpha$ coefficient's being over 0.80 means that it is highly reliable (Özdamar, 2007). Alpha reliability coefficient calculated for democracy scale has been found Cronbach $\alpha 818$ for subsidiarity sub dimension, Cronbach $\alpha$ 776 for participation in the decision sub dimension and Cronbach $\alpha 751$ for localization dimension. Edited item-total 
correlations calculated for each factor related to what extent scale items distinguish in terms of democracy's applicability level change between 36 and 65 .

\section{Findings}

In order for views of candidate teachers who participated in the study on applicability of Subsidiarity that is a sub dimension of organizational democracy according to gender to be revealed, $t$ test was conducted. According to $t$ test results, it is clear that there has been no meaningful difference among candidate teachers' views on applicability of Subsidiarity according to gender $\left[_{\mathrm{t}(365)}=2.163, \mathrm{p}>.01\right]$. However, when arithmetic means of male and female candidate teachers' views are compared, female candidate teachers $(\mathrm{X}=85,5635)$ are thinking more positively on Subsidiarity that is a sub dimension of organizational democracy scale than male candidate teachers $(X=83,7565)$.

According to T-test results, it is obvious that there has been no meaningful difference among candidate teachers' views on applicability of Participation in the Decision according to gender[ $\left.{ }_{t(365)}=.696, p>.01\right]$. When arithmetic means of candidate teachers' views on applicability of Participation in the Decision are compared, female candidate teachers $(\mathrm{X}=38,3175)$ are thinking more positively on Participation in the Decisionthat is a sub dimension of organizational democracy scale than male candidate teachers $(X=37,9304)$.

When views of candidate teachers who participated in the study are compared in terms of gender, according to T-test results, it is clear that there is no meaningful difference among their opinions about applicability of Localization and both female and male candidate teachers are thinking alike $\left[_{t(365)}=.021, p>.01\right]$. When arithmetic means of female candidate teachers' views $(X=28,9286)$ are taken into consideration, it can be stated that they have similar opinions with male candidate teachers $(\mathrm{X}=28,9130)$ (Table 2).

T-test was conducted to evaluate on the whole of OD scale of candidate teachers who participated in the study. According to t-test results, it has been understood that there is not meaningful difference in applicability of OD scale among genders $\left[_{\mathrm{t}(365)}=1.366, \mathrm{p}>.01\right]$. It is seen that, female candidate teachers $(\mathrm{X}=152.8095)$ are thinking more positively on applicability of OD than male candidate teachers $(X=150.6000)$ (Table 2).

Table 2. Candidate teachers' views on application of organizational democracy according to gender

\begin{tabular}{|c|c|c|c|c|c|c|c|}
\hline & gender & $\mathrm{N}$ & Mean & Std. Deviation & $\mathrm{sd}$ & $\mathrm{t}$ & $\mathrm{p}$ \\
\hline \multirow[t]{2}{*}{ Subsidiarity } & $\mathrm{f}$ & 252 & 85,5635 & 6,71206 & 365 & 2,163 & 031 \\
\hline & $\mathrm{m}$ & 115 & 83,7565 & 8,78654 & & & \\
\hline Participatio & $\mathrm{f}$ & 252 & 38,3175 & 4,82713 & 365 & ,696 & ,487 \\
\hline $\begin{array}{ll}\mathrm{n} & \text { in } \\
\text { decision } & \end{array}$ & $\mathrm{m}$ & 115 & 37,9304 & 5,19399 & & & \\
\hline Localizatio & $\mathrm{f}$ & 252 & 28,9286 & 6,24937 & 365 & ,021 & ,983 \\
\hline $\mathrm{n}$ & $\mathrm{m}$ & 115 & 28,9130 & 7,04816 & & & \\
\hline \multirow[t]{2}{*}{ OD } & f & 252 & 152,8095 & 12,66184 & 365 & 1,366 &, 173 \\
\hline & $\mathrm{m}$ & 115 & 150,6000 & 17,55433 & & & \\
\hline
\end{tabular}

According to the results of t-test conducted to compare opinions of candidate teachers who are graduate and those who continue theirundergraduate education about subsidiarity which is a sub dimension of organizational democracy,there is a meaningful difference between their opinions about applicability of subsidiarity dimension $\left.{ }_{\mathrm{t}(356)}=-5,452, \mathrm{p}<.01\right]$. Candidate teachers who have bachelor's degree $(X=88,6437)$ are thinking more positively about the applicability of organizational democracy than those who continue their undergraduate education ( $\mathrm{X}=83,7970)$ (Table 3$)$.

According to the results of t-test conducted to compare opinions of candidate teachers who are graduate and those who continue theirundergraduate education about participation in the decision which is a sub dimension of organizational democracy,there is a meaningful difference between their opinions $\left.{ }_{\mathrm{t}(356)}=-4,103, \mathrm{p}<.01\right]$. Candidate teachers who have bachelor's degree $(X=40,0230)$ are thinking more positively about the applicability of organizational democracy than those who continue their undergraduate education $(X=37,5572)$ (Table 3).

According to the results of t-test conducted to compare opinions of candidate teachers who are graduate and those who continue theirundergraduate education about localization which is a sub dimension of organizational democracy,there is a meaningful difference between their opinions $\left[_{t(356)}=-1.209, \mathrm{p}<.01\right]$. Candidate teachers who have bachelor's degree $(X=29,5977)$ are thinking more positively about the applicability of localization dimension than those who continue their undergraduate education $(\mathrm{X}=28,6162)$ (Table 3$)$.

According to the results of t-test conducted to compare opinions of candidate teachers who are graduate and those who continue theirundergraduate education about the applicability of organizational democracy in the whole,there is a meaningful difference between their opinions $\left[_{t(356)}=-4.763, \mathrm{p}<.01\right]$. Candidate teachers who have bachelor's degree $(\mathrm{X}=$ $158,2644)$ are thinking more positively about the applicability of organizational democracy dimension than those who continue their undergraduate education $(X=149,9705)$ (Table 3$)$. 
Graduate candidate teachers' having lessons in classroom training, working in private schools or working as private teachers can be shown among the reasons why there is difference between opinions of candidate teachers who are graduate and those who continue theirundergraduate education about applicability of organizational democracy according to education level.

Table 3. Views of candidate teachers on application of organizational democracy according to education level

\begin{tabular}{|c|c|c|c|c|c|c|c|}
\hline & education & $\mathrm{N}$ & Mean & Std. Deviation & $\mathrm{sd}$ & $\mathrm{t}$ & $\mathrm{p}$ \\
\hline Subsi- & Those who continue undergraduate ed. & 271 & 83,7970 & 7,94701 & 356 & $-5,452$ & 000 \\
\hline diarity & Graduates & 87 & 88,6437 & 4,14274 & & & \\
\hline \multirow[t]{2}{*}{ Participation in the decision } & Those who continue undergraduate ed. & 271 & 37,5572 & 5,34127 & 356 & $-4,103$ & 000 \\
\hline & Graduates & 87 & 40,0230 & 2,98047 & & & \\
\hline \multirow{4}{*}{$\begin{array}{l}\text { Locali- } \\
\text { zation } \\
\text { Organi- } \\
\text { zational } \\
\text { democracy }\end{array}$} & Those who continue undergraduate ed. & 271 & 28,6162 & 6,83620 & 356 & $-1,209$ & .228 \\
\hline & Graduates & 87 & 29,5977 & 5,74347 & & & \\
\hline & Those who continue undergraduate ed. & 271 & 149,9705 & 15,56227 & 356 & $-4,763$ & .000 \\
\hline & Graduates & 87 & 158,2644 & 8,13185 & & & \\
\hline
\end{tabular}

\section{Discussion and Suggestions}

In the first part of this study, dimensions of subsidiarity, participation and localization of the OD scale were examined by applying the opinions of the teacher candidates in the validity and reliability studies of the scale. The three-dimensional structure determined by EFA, was later examined by CFA, and the calculated accordance statistics were found to meet the criteria specified in the method.

According to this, it has been evaluated that the model-data compatibility of the scale is good. The alpha value calculated for the reliability of the scale scores was found as 81 for decentralized management. On this dimension, there are 19 (item 1 - item 19) articles. While Cronbach $\alpha$ was calculated as .77 for the sub dimension of decision participation which consists of 9 (20th item - 28th item) items, it was calculated as Cronbach $\alpha .75$ for the dimension of localization which consist of 8 (item 29-item 36) items . The fact that the corrected item-total correlations' - calculated on the OD raw scores-being higher than .30 proved that this subscale can be used in academic studies. On the other hand, alpha values calculated for the other three factors of scale are .75 and above, which is quite satisfactory.

In the second part of this study, it was also tried to find out the differences of the candidate teachers' opinions about the applicability of the OD scale according to their gender and education levels. According to gender of the candidate teachers who participated in the research, no difference was found between male and female candidate teachers' views on the applicability of subsidiarity. It has been determined that graduate students are thinking differently from those who continue their undergraduate education when examining the educational level of the candidates about the applicability of subsidiarity.

When the literature is reviewed, the subsidiarity aims to give administrative power to all the positions in the organization, by equipping positions, from the top to the bottom, with the rights to manage. It is believed that organization can be more effective in realizing its objectives as a whole by giving organization administrative power with subsidiarity (Başaran, 1988). It is stated that the most difficult obstacle to overcome the subsidiarity is the managers themselves. The managers' views on organization, approach to work, the perception of employees and interpretation style of others' expectations influence the transfer of authority (Wells, 1993)

The leader in the democracy is the one who tends to share his authority with the employees (Guastello, 1995). Administrators are expected to transfer their authorities to their stakeholders in order to ensure continuity of school development. One of the most important strategies in this regard should be to adopt an understanding of empowering subordinates and teachers in the school setting in order to create organizational democracy. Subsidiarity is administrator's authorizing others to operate the business and allowing certain activities to be done by others. Assigning powers to subordinates and other executives or authorizing them does not mean giving up their authority; because the last authorization for the assigned tasks belongs to the manager himself. However, subsidiarity can be expressed as temporarily and permanently giving authority to others to accomplish certain tasks and make decisions (Mucuk, 1997).

There were no significant differences in the applicability of decision participation according to gender in the survey conducted. Teacher candidates seem to agree on the feasibility of participating in the decision. However, according to the level of education, there was a significant difference in the opinions of candidate teachers regarding the applicability of participation in the decision. It seems that teacher candidates who graduated from university are thinking differently from candidates who continue their university education on the applicability of participating in the decision. When the field is scanned, according to the results of the research, "Participation of Secondary School Teachers in Decisions Related to Schools" conducted by Aksay and Ural (2008), teachers appear to have limited participation in the school administrative decisions. Açıkgöz (1984) found that teachers' attitudes to participation were lower than those of their 
participation. In the study conducted by Akdemir (2009), teachers stated that they had wanted to participate much more than they participated in the decisions taken at school. In addition to this, Bilgin (1996) concluded that teachers in primary schools generally did not participate adequately in the decisions taken at school in the survey about the evaluation of the degree of participation of primary school teachers in decisions taken by school administrations. In other words participative decision making is a process containing organizational effectiveness, organizational culture, organizational loyalty, organizational trust and organizational communication (Kilic Dogan, 2013).

English \& Hill (1990) suggest that if the school administrator consults to his subordinates and especially his supporters, the degree of reaching achievement will increase. According to Drucker (1992), the decision making is the most important of the duties of the manager and the manager must make a special effort to make an effective decision. Participation in the decision, in other words, participation in the management, is a necessary feature in terms of motivating the worker. The benefits of taking part in the management aim to change the attitudes and habits of the working groups, to balance the organizational goals for personal purposes, to motivate the staff, to reduce the number of leaving and quitting work, and to reduce the situations where employees are openly or covertly resistant to management decisions (Eren, 1993).

There is no difference in the opinions of the teacher candidates participating in this study on the issue of localization according to gender. In addition to this, differences were found in their views on the issue of localization according to their educational level. Localization involves the transfer of decision-making authority and power among different levels and actors in the education path (Rado, 2001). In the field study, Usluel (1997) and Atasayar (2005) have some research on localization in education. While Usluel, from the researchers tries to reveal "the opinions of Ministry of Education central administrators about the localization", Atasayar aims to reveal "the opinions of the Ministry of Education provincial administrators about the localization". While paperwork caused by correspondence between central and provincial organizations leads to waste of labor and time, lack of communication in the education system causes the services to come to a halt. Sometimes, in order to gather information on one subject, submitting the works to the bureau, getting the approval of many people proliferate so much that the goals of the organization are ignored. In this case, fulfilling the requirements of paperwork takes the place of developing organizational goals (Peker, 1995). It is therefore necessary to redefine the roles, duties, powers and responsibilities of local administrations in local government, local government units representing the authority of central government in the process of restructuring of provincial-level national education and school administrations (Şişman \& Turan 2003).

\section{Conclusion}

This study was carried out with candidate teachers who receive pedagogical formation training at Istanbul University. A total of 436 volunteer candidate teachers participated in the study. 370 scale forms of the participants of the study were considered valid. CFA and EFA were implemented on the data gathered from 370 candidate teachers. It was found that the scale consisted of three subscales including subsidiarity, participation in the decision and localization. It was aimed to determine whether there were significant differences among candidate teachers' views about the practicality of the organizational democracy scale according to gender and education level of candidate teachers by employing T-test.

No significant differences were found among candidate teachers' opinions about the practicality of subsidiarity according to gender.

It was determined that there were not significant differences among candidate teachers' opinions about the practicality of participation in the decision according to gender.

According to the results of the analysis, it was found that there were not significant differences between the opinions of female and male candidate teachers about the applicability of localization and both female candidate and male candidate teachers had similar opinions.

Results of T-test which was conducted to evaluate the organizational democracy scale in its totality showed that there were not significant differences about the applicability of the organizational democracy scale between sexes.

It can be seen that there is a significant difference between the opinions of candidate teachers who completed their bachelor degree and those who continue about the practicality of the subscale of subsidiarity of the organizational democracy scale.

It can be seen that there is a significant difference between the opinions of candidate teachers who completed their bachelor degree and those who continue about the practicality of the subscale of participation in the decision of the organizational democracy scale.

It can be seen that there is a significant difference between the opinions of candidate teachers who completed their bachelor degree and those who continue about the practicality of the subscale of localization of the organizational democracy scale. 
It can be seen that there is a significant difference between the opinions of candidate teachers who completed their bachelor degree and those who continue about the practicality of the organizational democracy scale at large.

Value conflict, power exceeding and sense of belonging can be considered as the obstacles to have democracy at school (Truchot, 2004). There are some steps that should be taken to solve such a kind of issues. One of these steps is that Ministry of Education should have a more functional structure and more power should be given to the provincial administration. Other steps include identifying the problem and solving it at its own place and participation of society in a large scale should be ensured in the process of problem-solving and educational administration. (Şişman \& Turan 2003).

\section{Limitations}

In this study, it was aimed to identify candidate teachers' views on applicability of organizational democracy and adoption level with organizational democracy scale. Also, this scale can be modified for primary school and branch teachers, and their level of organizational democracy adoption can be compared. An extensive study can be conducted by comparing school administrators' and teachers' adoption level of organizational democracy in Turkey by means of this scale. This kind of studies can be conducted by receiving and comparing opinions of teachers who have different ethnic backgrounds. Besides that, a study that aims to compare theology and education faculty students' opinions can be planned.

\section{References}

Acikgoz, K. (1984). Participative decision-making with teachers at schools (Unpublished Doctoral Dissertation). Hacettepe University, Ankara.

Akdemir, A. S. (2009). Participative decision-making with teachers working at state primary schools (Unpublished Master's Thesis). Beykent University, Institute of Social Sciences, Istanbul.

Aksay O. \& Ural A. (2008). Secondary school teachers' participation in decision-making at schools. Journal of Turkish Educational Sciences, 6(3), 433-460.

Aktan, C. C. (1999). 21th century and constitutional democracy. Retrieved from www.canaktan.org/politika/demokrasi/makaleler/anayasal-demokrasi.htm

Askun, I. C. (1970). Authority transfer in management. Journal of Eskisehir Financial and Trade Sciences Academy, $6(1), 68$.

Atasayar, H. H. (2005). Ideas of the provincial managers of the Ministry of National Education about localization (Unpublished Master's Thesis). Kırıkkale University, Institute of Social Sciences, Kırıkkale.

Bakan, I., \& Buyukbese, T. (2005). Participative decision-making: To what extent do employees wish to participate in decision-making? Afyon Kocatepe University Journal of Faculty of Financial and Managerial Sciences, 34(2).

Basaran, I. E. (1988) Educational administration. Ankara: Gul Publications.

Basaran, I. E. (1998a). Human relations in management. Ankara: Adnan Web Tesisleri Press.

Bilgin, T. (1996). Evaluation of participative decision-making status of teachers working at Zonguldak primary schools (Unpublished Master's Thesis). Gazi University, Institute of Social Sciences, Ankara.

Brown, T. A. (2006). Confirmatory factor analysis for applied research. New York: Guilford.

Bursalioglu, Z. (1991). New structure and behavior in school management. Ankara: Pegem Publications.

Buyukozturk, S. (2013). Handbook of data analysis for Social Sciences. Ankara: Pegem Academy.

Buyukozturk, S. (2002). Factor analysis: Basic concepts and usage for scale development. Educational Administration in Theory and Practice, 32(32), 470-483.

Can, H. (1992). Organization and management. Ankara: Adim Press.

Celikten, M. (2001). Decision-making process at effective schools. Erciyes University Journal of Social Sciences, 11, $1-12$.

Dalton, R. (2004). Democratic challenges, democratic choices. Oxford: Oxford University Press.

Delaunay, M. (2004). Democracy, authority and school. Cahiers Pedagogiques, 433.

Dewey, J. (2010). School and society (H. Avni Basman, Trans.). Ankara: PegemA.

Drucker, P. (1992). The effective executive. New York: Harper and Row.

English, Fenwick W. \& Hill, John C. (1990). Restructuring: The principal and curriculum change. A Report of the 
Curriculum Council. Virginia: National Association of Secondary School Principals Publications.

Erdem, F. (1996). Organization culture. Antalya: Friedrich-Naumann Foundation and Akdeniz University Publications.

Eren, E. (1993). Management and organization. Istanbul: Beta Publications.

Ergun, I. (2006). Concept of governance in local administrations and comparing with European Union (Unpublished Master's Thesis), Dokuz Eylul University, Institute of Social Sciences, Izmir.

Guastello, S. J. (1995). Facilitative style, individual innovation and emergent leadership in problem solving. The Journal of Creative Behavior, 29(4), 226.

Harrison, J. S., \& Freeman, E. (2004). Special topic: Democracy in and around organizations. Academy of Management Executive, 18, 49-53.

Hu, L. T., \& Bentler, P. M. (1999). Cut-off criteria for fit indexes in covariance structure analysis: Conventional criteria versus new alternatives. Structural Equation Modeling, 6, 1-55.

Isbasi, J. O. (2000). The Influential role of the employees trust in a supervisor and perceptions of organizational justice in the occurrence of the employees propensity of displaying organizational citizenship behavior (Unpublished Master's Thesis). Akdeniz University, Institute of Social Sciences, Antalya.

Karaca, N. (2001). Level of teachers' participation in decision-making related to school management at primary schools (Marmaris case) (Unpublished Master’s Thesis). Gazi University, Institute of Social Sciences, Ankara.

Karakutuk, K. (2001). Democratic and secular education. Ankara: Ani Publications.

Kilic Dogan, E (2013). Participative decision making: Sinop University sample. Turkey Croatian Journal of Education, 15(2), 465-489.

Kocabas, I., \& Gokbas, M. (2002). Participation in decision-making in education. Journal of National Education, 155(1), 170-181.

Kocel, T. (2003). Business management. Istanbul: Beta Publications.

Mucuk, I. (1997). Modern business. Istanbul: Turkmen Bookstore.

Mulder, M., \& Wilke, H. (1970). Participation and power equalization. Organizational Behavior and Human Performance, 5(5).

Onaran, O. (1974). Authority transfer-authority take-over. Journal of Public Management, 7(2), 3-21.

Ozalp, I., Koparan, C., \& Berberoglu G. (1997). Management and organization. Eskisehir: Anadolu University Publications.

Özdamar, K. (2007). Statistical data analysis with package softwares. Eskisehir: Nisan Bookstore.

Peker, Ö. (1985). Continuum in management improvement. Ankara: Institute of Turkey and Middle East Management Publications.

Rado, P. (2001). Transition in education. Budapest: Open Society Institute.

Rizvi, F. (2005). In defence of organizational democracy. In Smyth, J. (Ed.), Critical perspectives on educational leadership, 138-155. New York: Routledge.

Sadykova, G., \& Tutar, H. (2014). a study on the relationship between organizational democracy and organizational dissent. Journal of Business Sciences, 2 (1)1-16.

Scholl, W. R. (2003). Organizational culture: The social inducement system. Retrieved from http://www.uri.edu/research/Irc/Scholl/Notes/Culture.html

Seker, G. (2010). The level of ability to adopt and apply organizational democracy to primary schools according to perceptions of teachers and administrators (Unpublished Master's Thesis). Van Yuzuncu Yil University, Institute of Social Sciences, Van.

Simsek O. F. (2007). Introduction to structural equation modelling: Basic concepts and LISREL applications. Ankara: Ekinoks Publications.

Sisman, M. (2006). Democracy in education and social justice: The unchanged myth of Turkish educational system. Searching for New Paradigms for Turkish Educational System Proceedings, November 4-5, Ankara: Eğitim-Bir Sen Publications, 291-305.

Sisman, M., \& Turan, S. (2003). Localization in educations and democratization. Educational Administration in Theory and Practice, 34, 300-315. 
Stohl, C., \& Cheney, G. (2001). Participatory processes/Paradoxical practices: Communication and the dilemmas of organizational democracy. Management Communication Quarterly, 14, 349-407.

Tabachnick, B. G., \& Fidell, L.S. (2001). Using multivariate statistics (4th ed.). Boston: Pearson/Allyn and Bacon.

Truchot, V. (2004). School and democratic values. Retrieved from http://www.cifedhop.org/Fr/Publications/Thematique/thematique4/Truchot.pdf

Usluel, K. Y. (1997). Views of the Ministry of National Education headquarters on localization. Education and Science, 2l(103), 25-36.

Vroom, V. H., \& Yetton, P. W. (1973) Leadership and decision making. Pittsburgh: University of Pittsburgh Press.

Wells, R. G. (1993). Authority transfer (Vedat Uner, Trans.) İstanbul: Rota Publications.

Yazdani, N. (2009). Organizational democracy and organizational structure link: Role of strategic leadership \& Environmental uncertainty. Business Review, 5(2), 51-74.

\section{Copyrights}

Copyright for this article is retained by the author(s), with first publication rights granted to the journal.

This is an open-access article distributed under the terms and conditions of the Creative Commons Attribution license which permits unrestricted use, distribution, and reproduction in any medium, provided the original work is properly cited. 